\title{
スプリント療法により咬合再構成を行った症例 一一顆頭安定位を求めて——
}

Occlusal reconstruction after determination of the mandibular position by splint treatment - a case report

松本 晃治

Koji Matsumoto Keyword : occlusal reconstruction, dual bite, stabilization type splint
キーワード: 咬合再構成, 二態咬合, スタビリゼーションタイプスプリント, 歯周炎,
歯周再生療法

This paper is to present a case of a patient with moderate periodontal disease and dual bite and discuss importance of assessment and diagnosis and how to utilize splint to achieve stable occlusion.<Clinical Summary $>$ At the time of the first visit the female patient was 60 years old; probing pocket depth exceeded $6 \mathrm{~mm}$ in some areas; in the occlusal examination lack of occlusal contact was observed in the molar region at the habitual closure position; and cuspal interference occurred on the left and right second molars during lateral movement and group function were seen on both sides. Premature contact occurred between 7 and $\overline{7}$ upon the closure with the jaw muscles relaxed. <Therapeutic Process $>$ The patient was instructed to wear stabilization splint at all time, and mandibular position was check every 3-4 weeks along with adjustment of the splint. Over the course of this treatment provisional restoration stayed intact, and neither washout of temporary cement nor temporomandibular disorder occurred. Determination of mandibular position by stabilization splint does not only avail accurate diagnosis, but also help realizing patient specific and stable condylar position, which greatly merited the subsequent prosthetic procedures and helped keeping mandibular position stable.

\footnotetext{
二態咬合を有する中等度歯周炎患者にスプリントにより顎位を決定し咬合再構成を行ったケースを提示して, 術 前の診查・診断の重要性と咬合の安定を図るための方法について考察する。【症例概要】患者は初診時 60 歳の女性 で歯周組織検查ではプロービングポケットデプス（PPD）が 6mm を超える部位が認められ，咬合検查では習慣性 の閉口位では，臼歯においては咬合接触関係が認められない部位が存在し，側方運動時に左右の第二大自歯に咬頭 干渉しているのが認められ，左右ともグループファンクションであった．筋の緊張を解除した状態で閉口させると

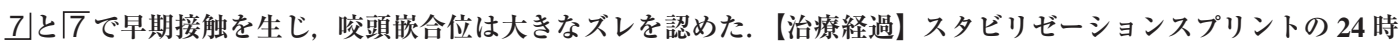
間の使用を指示し， 3〜4 週ごとに下顎位の確認とスプリントの調整を行った. その後，プロビジョナルレストレー ションを装着したが，プロビジョナルレストレーションの破損や仮着セメントのウォッシュアウト，顎関節症状な どは認められなかった．スタビリゼーションスプリントによる顎位の決定は，口热内に不可逆的な変化を与える前 に正確な診断が行えるほか, 患者固有の安定した顆頭位を具現化できる利点があり, その後の補経操作が容易に行 え，術後の顎位の安定も得やすいことが確認できた【【顎咬合誌 34(1・2)：15-23，2014】
}

\section{緒言}

口腔の健康をより長期に安定したものにするためには, 咬合の問題が解決されなければならないし，また咬合を 十分に考慮しない歯科治療は長期的にみて患者の利益に はならないと筆者は考える。一口腔単位として口腔疾患 を捉える場合, 術前の診査・診断はきわめて重要と考え

まつもと歯科医院 $\overline{7} 870-0919$ 大分県大分市新栄町 12-20 Tel : 097-552-8211

受付日：2012 年 1 月 13 日

受理 : 2014 年 2 月 18 日
る. 特に顎位の診断は咬合再構成が必要なのか, 術前の 顎位を利用しての治療で可能なのかを見極めるうえで欠 かせない診査項目である。

咬合再構成が必要な症例に対し顆頭安定位で顎位を決 定する方法としてスプリント療法は有効で, その後のプ ロビジョナルレストレーションによる評価は, その後の 補綴治療や術後の咬合の安定にも大きく関係する.

そこで，二態咬合を有する中等度歯周炎患者にスプリ ントにより顎位を決定し咬合再構成を行ったケースを提 示し, 術前の診査・診断の重要性と咬合の安定を図るた 
めの方法について考察する.

症例

\section{概要}

患者：女性, 60 歳

初診: 2008 年 3 月 7 日

職業：主婦

主訴 : 3歯肉の腫脹

喫煙歴：なし

全身既往歴：高血圧

\section{1. 初診時口腔内所見}

初診時口腔内写真 (図 1), 同歯周組織検査表（図 2) および同エックス線写真（図 3，4）を示す.

\section{2. 歯周組織検査}

プロービングポケットデプス（PPD）が $6 \mathrm{~mm}$ を超え る部位は72， $14567 ，$ 3， 77であった. エックス 線写真より 21345, 3に垂直性骨吸収を認めた。深
いポケットと, 付着の喪失が認められたが, 辺縁歯肉の 歯石の沈着や発赤は顕著ではなかった。

\section{3. 咬合状態の検査}

習慣性の閉口位では前歯のカップリングは認められた ものの, 臼歯においては咬合接触関係が認められない部 位が存在した。

側方運動時において上下顎左右側の第二大臼歯が干渉 しているのが認められた， 犬歯によるガイドは浅く左右 ともグループファンクションであった. フレミタスは4 に認められた。

咬合, 顎関節に関する問診では患者自身の自覚症状は 特になかった。最大開口量は $50 \mathrm{~mm}$, 開閉口時の顎関節 のクリッキング, 捻発音, 癒着等は認められなかった.

パノラマエックス線所見では左右顎関節の著しい形態 異常や左右差は認められなかった。

筋の緊張を解除した状態で閉口させると7りと「で早期 接触を生じ, 咬頭嵌合位は大きなズレを認め, 二態咬合 を呈していた（図 5).

上顎スピーカーブに比して下顎は彎曲の度合いが強く,
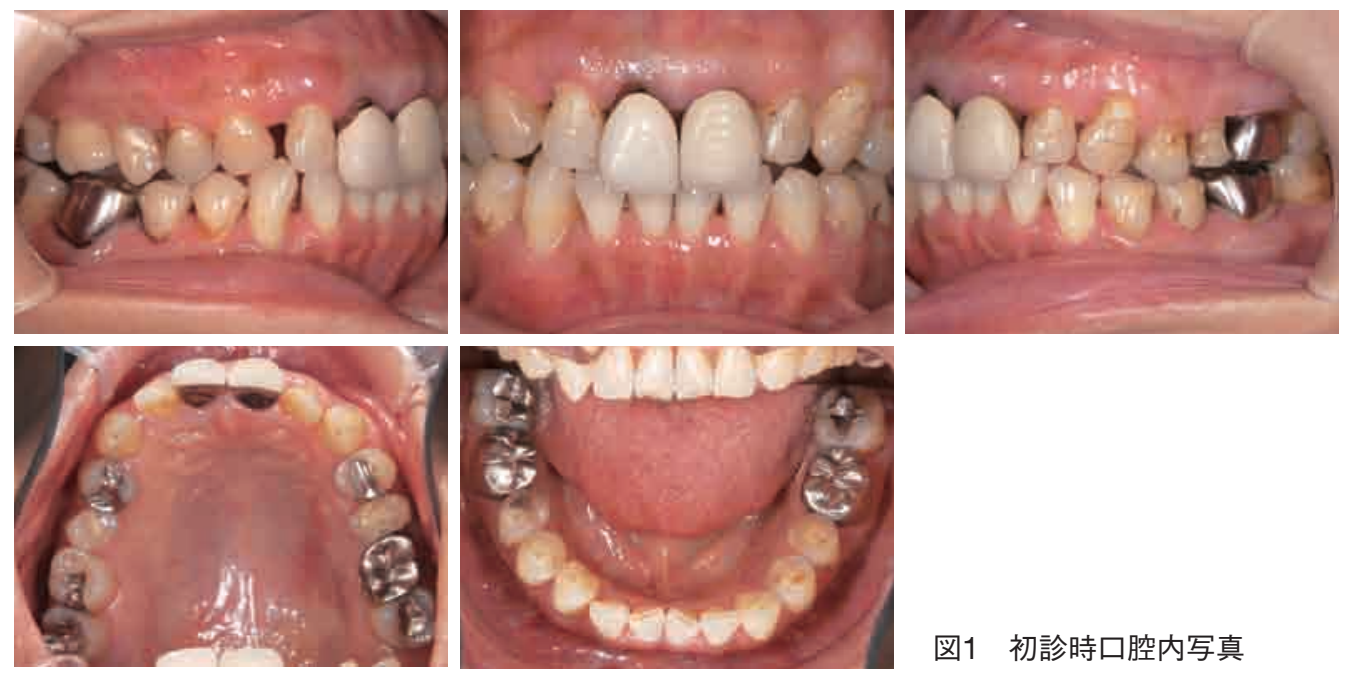

図1初診時口腔内写真

\begin{tabular}{|c|c|c|c|c|c|c|c|c|c|c|c|c|c|c|}
\hline 0 & 0 & 0 & 0 & 0 & 0 & 0 & 0 & $\overline{0}$ & 0 & 1 & 1 & 0 & $\overline{0}$ & Mob \\
\hline$\ldots$ & 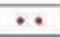 & 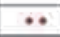 & $\cdots$ & & - & $\cdots$ & - & & & $\cdots$ & $\cdots$ & $\cdots$ & $\cdot$ & BOP \\
\hline 844 & 333 & 334 & 333 & 323 & 533 & 322 & 534 & 333 & 333 & 334 & 337 & 534 & 334 & Buc \\
\hline 7 & 6 & 5 & 4 & 3 & 2 & 1 & 1 & 2 & 3 & 4 & 5 & 6 & 7 & Maxi \\
\hline 523 & 223 & 323 & 323 & 333 & 333 & 433 & 333 & 333 & 333 & 633 & 445 & 433 & 335 & Pat \\
\hline$\cdot$ & $\ldots$ & & & & & .. & .. & . & $\cdot$ & $\ldots$ & $\ldots$ & . & . & \\
\hline & & & & & & & & & & & & & & Furc \\
\hline$\cdot$ & 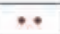 & & $\cdots$ & $\cdots$ & , & & & & & & • & $\cdots$ & $\cdots$ & \\
\hline 333 & 333 & 333 & 336 & 333 & 323 & 222 & 222 & 222 & 323 & 333 & 334 & 333 & 538 & Lin \\
\hline 7 & 6 & 5 & 4 & 3 & 2 & 1 & 1 & 2 & 3 & 4 & 5 & 6 & 7 & Mnad \\
\hline 333 & 323 & 333 & 336 & 4103 & 322 & 223 & 323 & 323 & 323 & 333 & 333 & 334 & 637 & Buc \\
\hline & & • & $\cdots$ & $\cdots$ & $*$ & & & & & & & $\cdot$ & $\cdot$ & BOP \\
\hline 0 & 0 & 1 & 1 & 0 & 0 & 0 & 0 & 0 & 0 & 0 & 0 & 0 & 0 & Mob \\
\hline
\end{tabular}

72 , $144567,3, \quad 7$ に深い歯周ポケッ トを認める. 
$\overline{76167}$ は近心傾斜していた.

スタディモデル作製後フェイスボウトランスファーを 行い, 術者誘導による中心位にて模型を咬合器に付着し 咬合診査を行った，術者誘導による中心位と咬頭嵌合位 (ICP）のズレが認められた。 口腔内での ICPでの犬歯 関係は両側とも $\mathrm{M}$ 型を示したが, 中心位においては D 型であった。

\section{II. 診断}

二態咬合を伴った歯周炎

\section{III. 治療計画}

歯周初期治療後に垂直性骨欠損を有する部位にエムド
ゲインを用いた再生療法を行った。 また歯周治療と並行 してスタビリゼーションタイプのスプリントを装着し （図 6), 顆頭安定位を模索, その後, 診断用ワックス アップを行い, 補綴処置の最終計画を立案, プロビジョ ナルレストレーションを装着し, 顎位の安定と患者の適 応を観察し, 最終補緅へ移行することとした。

\section{IV. 治療経過}

スタビリゼーションスプリントの 24 時間の使用を指 示し, 装着期間は 9 力月であった。 その間, 3 〜 週ご とに下顎位の確認とスプリントの調整を行った。 スプリ ント上の圧痕や咬合紙の印記の状態, スタディモデルを 顆頭安定位で咬合器付着を行い, 下顎位が収束したこと

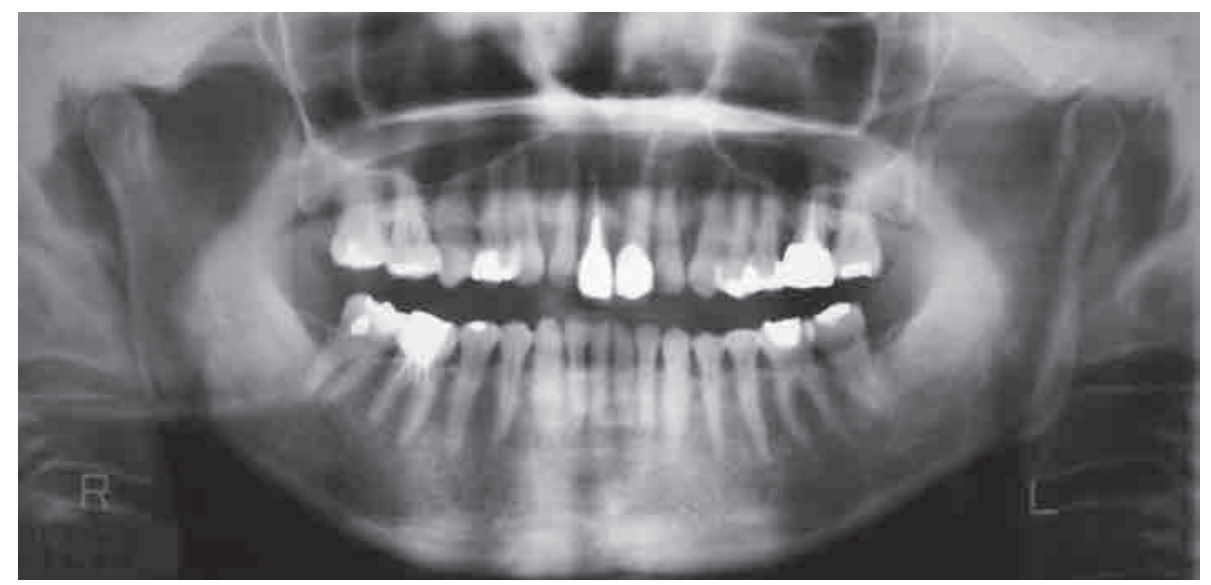

図3 初診時パノラマエックス線写真

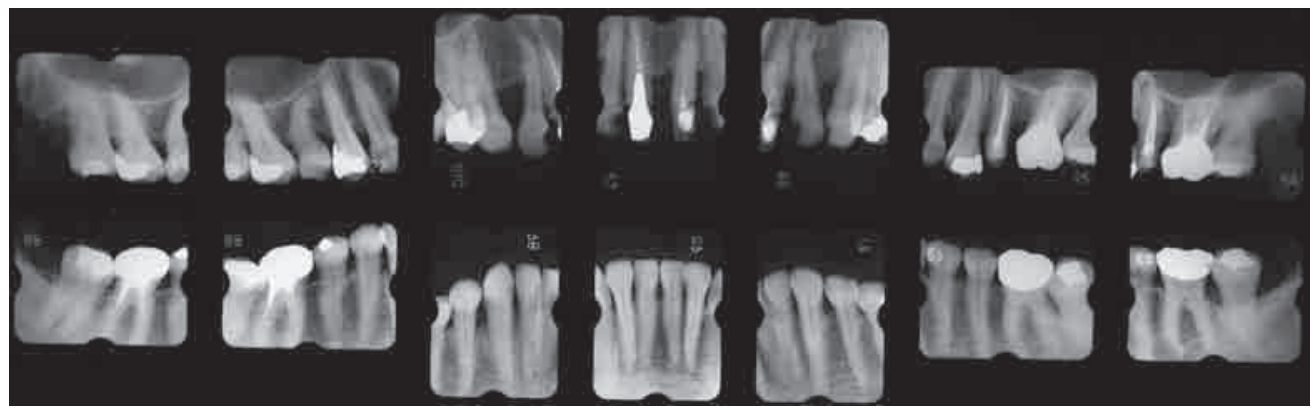

図4 初診時全顎デンタルエックス線写真

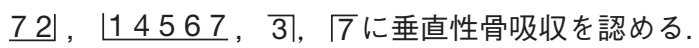
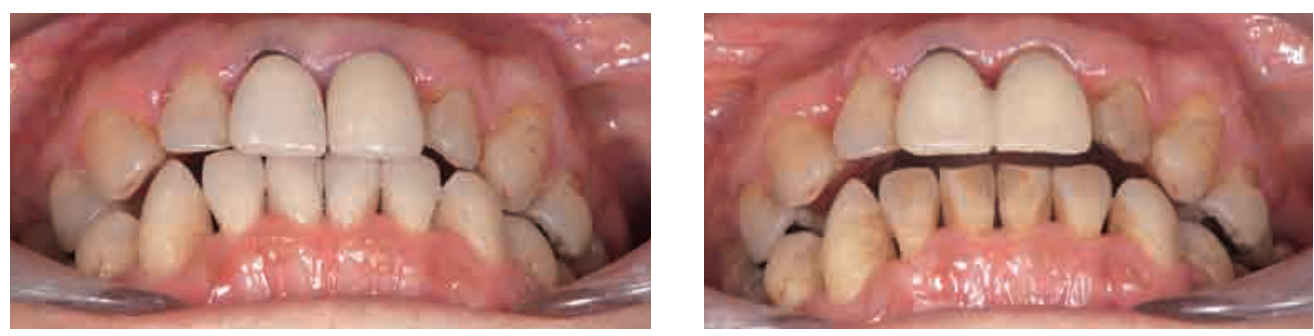

図5アンテリアカップリングの状態

左：初診時咬頭嵌合位 咬頭嵌合位においてアンテリアカップリングは認められる

右：初診時中心位 中心位においては上下前歯の接触は認められない 
をもって下顎位が安定したと判断した.

下顎位が安定し収束したことを確認した後に診断用 ワックスアップを作成した。下顎位はクロックワイズ ローテーションを呈し, 最後臼歯に早期接触を認めた (図 7).

顆頭安定位では最後臼歯で早期接触を認め, 咬合高径 は挙上された状態であった.この咬合高径では審美的に 問題が生じ, かつ前歯部のカップリングやアンテリアガ イダンスの付与に困難が生じるため, 咬合高径を初診時
の状態まで戻す必要があると判断した. 中心咬合位を検 討するために, 模型上で顆頭安定位と咬頭嵌合位が一致 するように早期接触を削合し咬合調整を行った。咬合高 径は初診時の咬合高径を参考にし, 早期接触部位で挙上 された咬合高径に対し切歯指導ピンで $3 \mathrm{~mm}$ 咬合高径を 低くした状態まで咬合調整を行った（図 8).

その後アンテリアカップリング, 犬歯ガイド, 臼歯 部咬合接触関係が正常に得られるように診断用ワック スアップにて検討した（図 9). 適正なアンテリアガイ

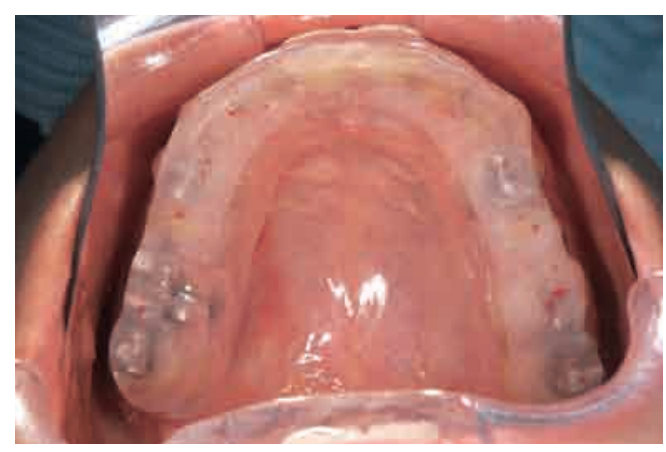

図6 スタビリゼーションスプリント装着時
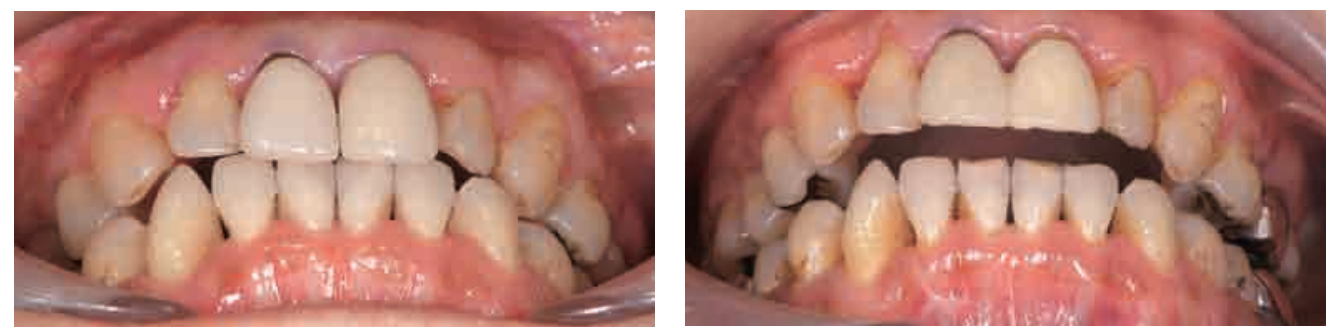

図7 スプリント治療後のアンテリアカップリングの状態

左：初診時咬頭嵌合位 咬頭嵌合位においてアンテリアカップリングは認められる

右：顆頭安定位 下顎は初診時の中心位よりもさらにクロックワイズローテーションを呈し, 前歯 開口量が増えた
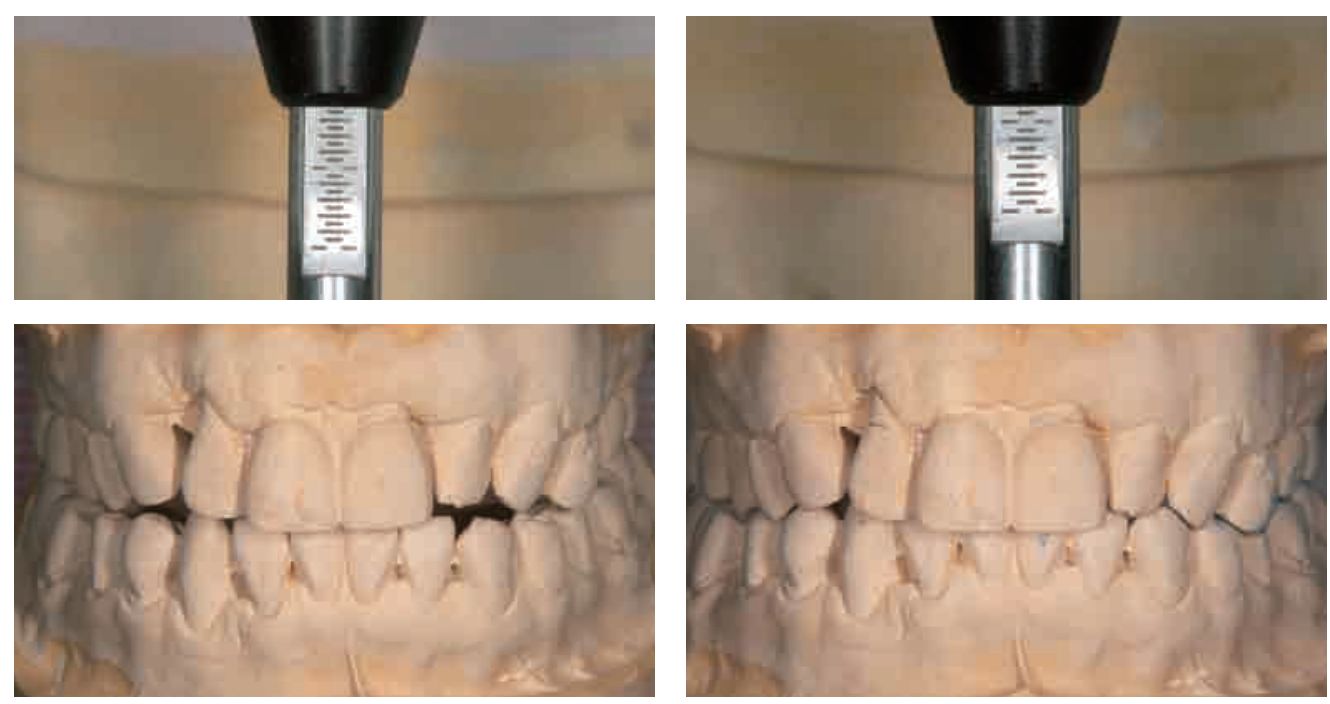

図8 咬合器上での咬合調整

左：調整前, 右：調整後, 指導ピンで3mm咬合を下げた. 
ダンスを付与するためにオーバーバイトは $4 \mathrm{~mm}$, オー バージェットは $3 \mathrm{~mm}$ となるように, 下顎前歯部切端お よび唇面にワックスを築盛し, また, 適正な切歯路角を 与えるために上顎前歯部の口蓋側面は削合した.

診断用ワックスアップを元に作成したプロビジョナル レストレーションを装着し, 顎位の安定, 歯周組織との 調和, 歯髄の保護を図った（図 10).

プロビジョナルレストレーション装着後 8 カ月に $7 \mid 7$ のプロビジョナルレストレーションが破損した（図 11). 下顎位の安定が不十分であると判断し，再度スプリント を装着し, 咬合器上で顎位の確認を行った. その後, 再 びプロビジョナルレストレーションを作成した（図 12).
最終のプロビジョナルレストレーション装着期間中 のプロビジョナルレストレーションの破損や仮着セメ ントのウォッシュアウト, 顎関節症状などは認められ なかったため, 最終補綴物作成を行った。最終補綴物は Sequential Cementation ${ }^{2)}$ により，下顎前歯部，上顎前 歯部, 下顎臼歯部, 上顎臼歯部の順で作成した。

図 13 は最終補緅物装着時の口腔内所見である。

オーバーバイトは $4 \mathrm{~mm}$, オーバージェットは $3 \mathrm{~mm}$ となるようにオールセラミックスクラウンとラミネート ベニアによる前歯の修復により適切な犬歯誘導とアンテ リアガイダンスが得られた。

臼歯部補綴は小臼歯部にオールセラミックスクラウン,
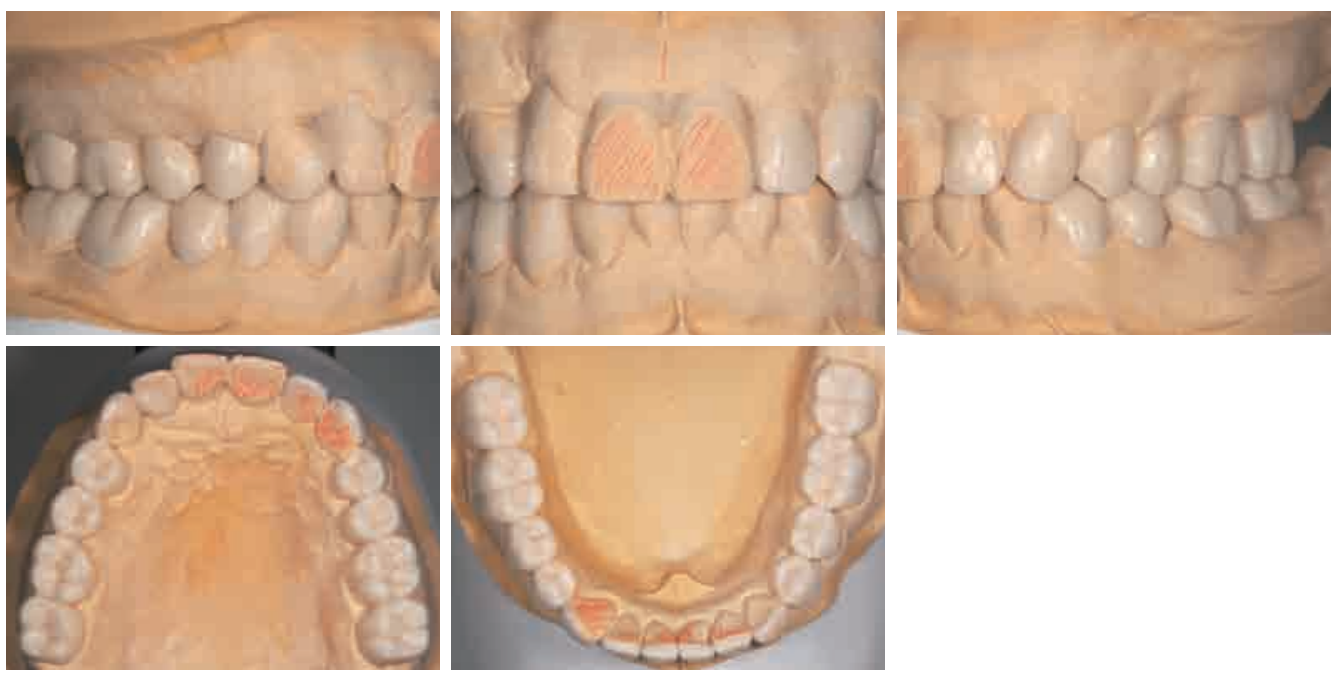

図9診断用ワックスアップ

適正なアンテリアガイダンスを付与するためにオーバーバイトは $4 \mathrm{~mm}$, オーバージェットは $3 \mathrm{~mm}$ となるように, 下顎前歯部切端および唇面にワックスを築盛し, また, 適正な切歯路角を与えるた めに上顎前歯部の口蓋側面は削合した.
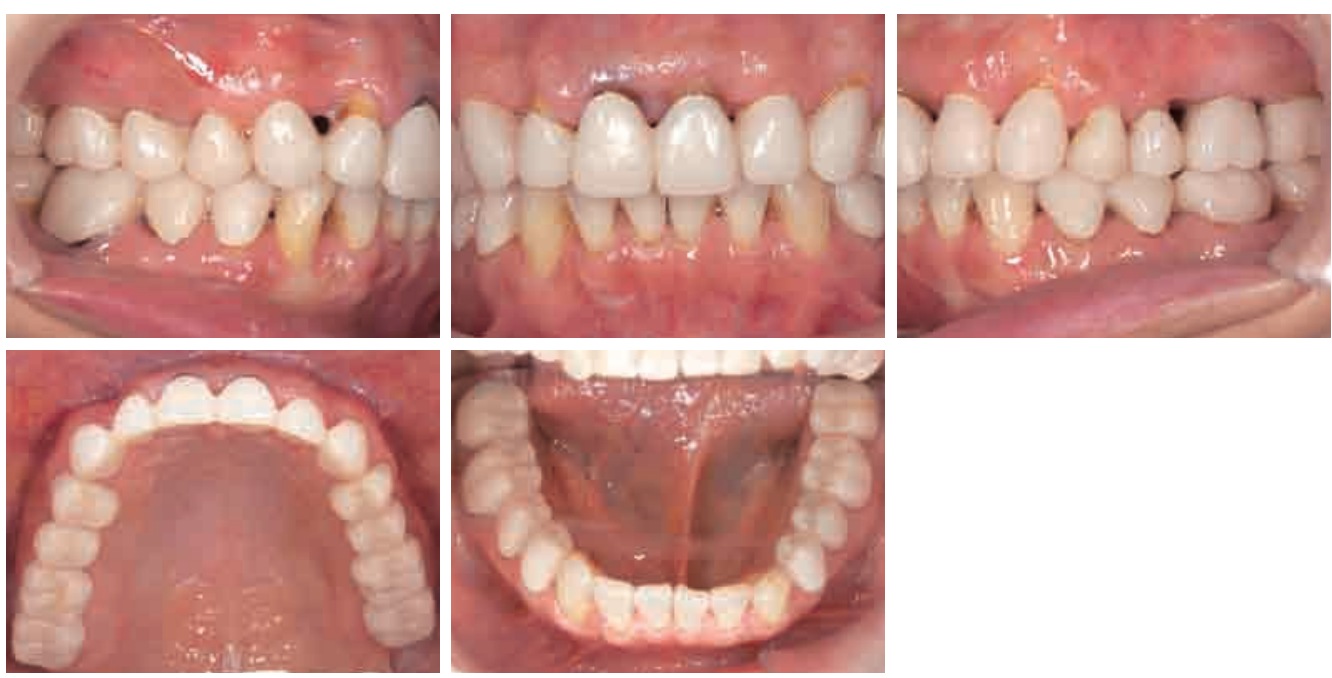

図10 プロビジョナルレストレーション装着時

診断用ワックスアップを元に作成したプロビジョナルレストレーションを装着し, 顎位の安定, 歯 周組織との調和, 歯髄の保護を図った. 
図11 プロビジョナルレストレーション装着後8カ月

17のプロビジョナルレストレーションの頓側咬頭の破折を認めた.
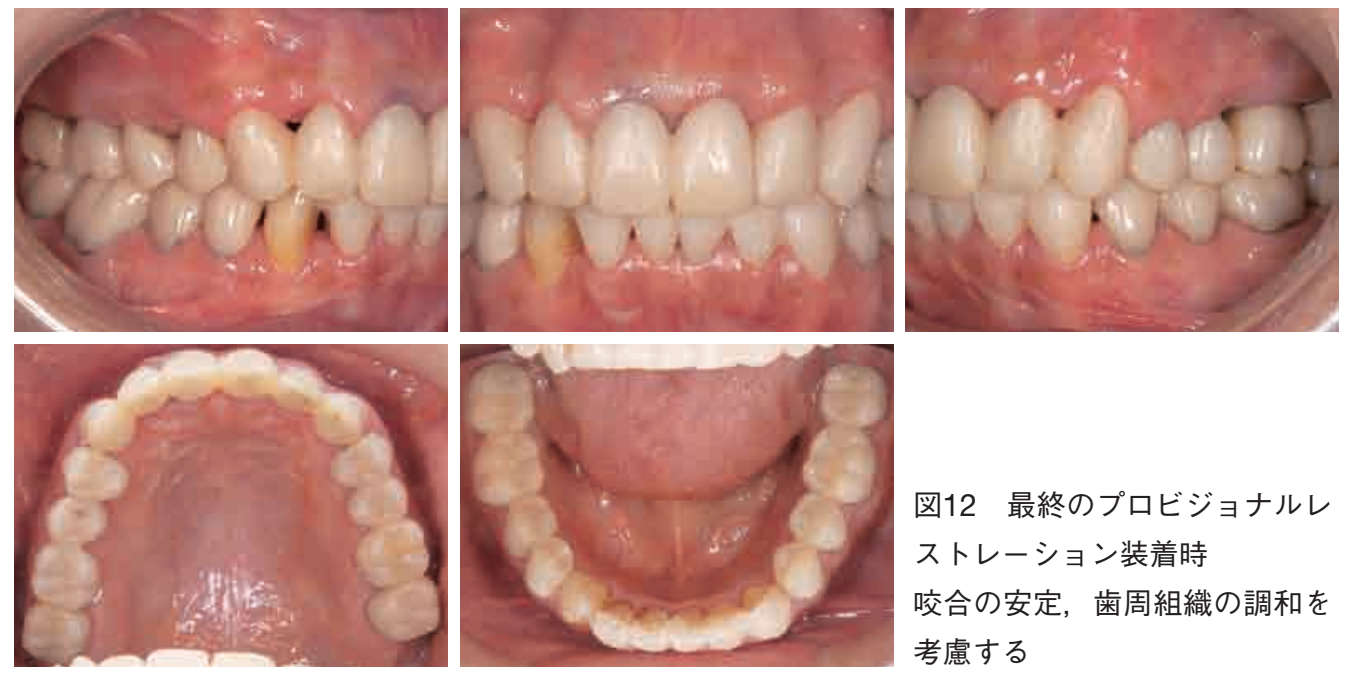

図12 最終のプロビジョナルレ

ストレーション装着時

咬合の安定，歯周組織の調和を

考慮する

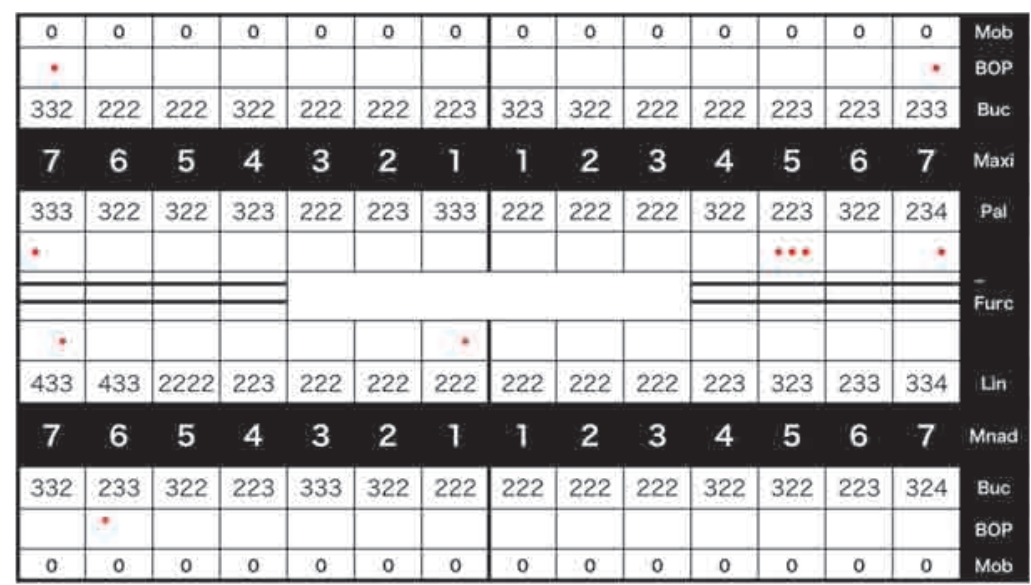

図13 治療終了時歯周組織検査

再生療法を行った上顎前歯部, 上顎左側小臼歯部, 下顎右側犬歯部の歯周ポ ケットは減少した.

第一大歯はセラモメタルクラウン, 第二大臼歯はゴー ルドによる鋳造冠により, 適切な臼歯部のバーチカルス トップを与えた。

\section{考察}

上顎前歯部の審美性は歯䅡線の連続性は適切に得られ なかった。

術後補綴物の破損や咀嚼障害, 顎関節障害等は認めら れず，経過は良好であった。

MacNeil 1) は，患者の有する咬合が生理的咬合か病 的咬合かを診断することの重要性を述べている．生理的 咬合とは咀嚼器官に機能的平衡性が存在している咬合 であり，歯に加わるストレスが正常に分散され，そのス トレスと支持組織, 咀嚼筋および顎関節の適応能力がバ 


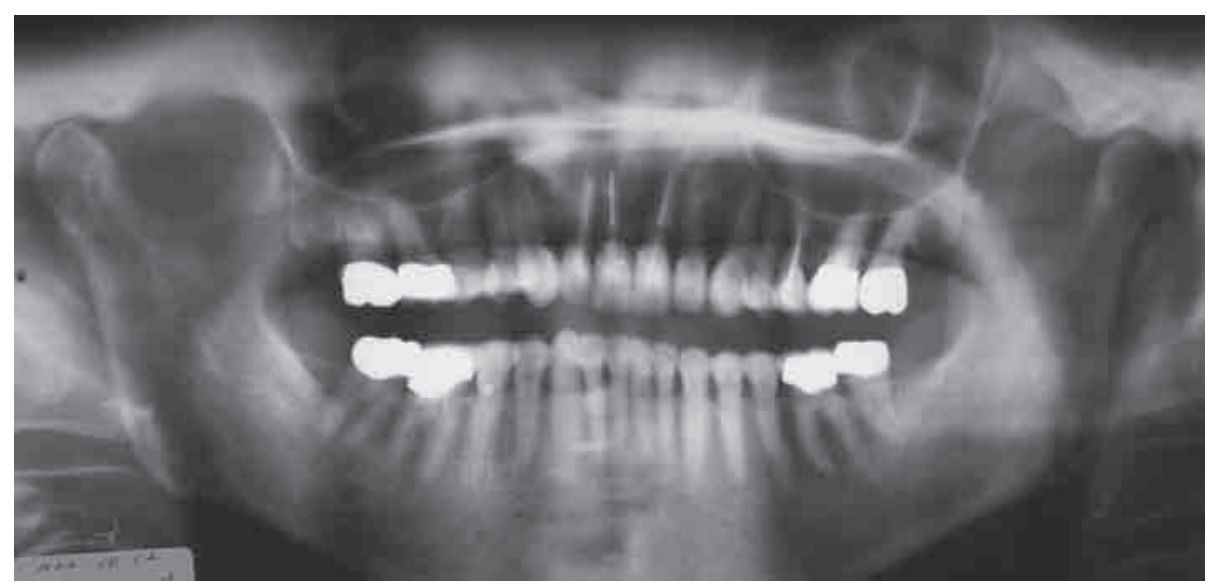

図14 治療終了時パノラマエックス線写真

再生療法を行った上顎前歯部, 上顎左側小臼歯部, 下顎右側犬歯部の歯槽骨の平坦化と歯 槽硬線の明瞭化が認められた.

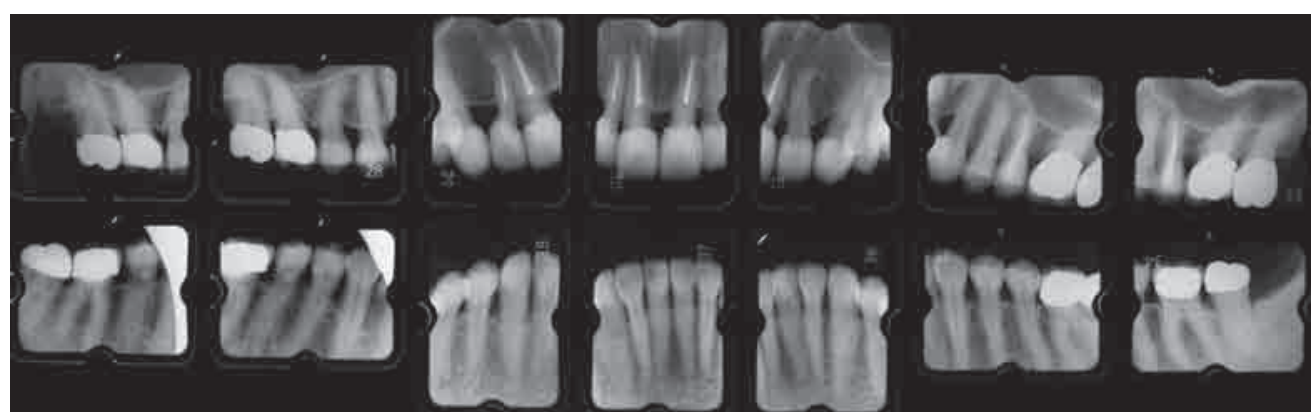

図15 治療終了時全顎デンタルエックス線写真.
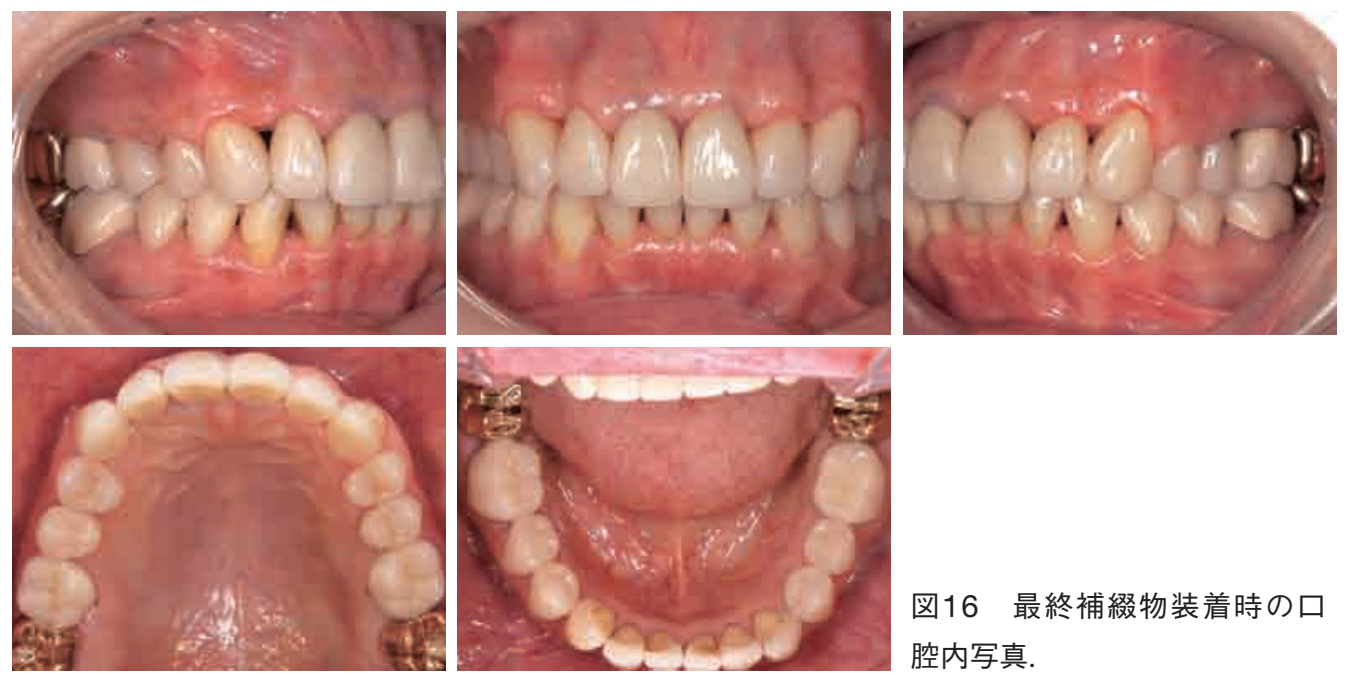

図16 最終補緅物装着時の口 腔内写真.

ランスがとれている状態とされ，咬頭嵌合位で治療可能 な咬合状態である。一方, 病的咬合とは咀嚼器官が平衡 性を失った状態で, 歯に加わるストレスが咀嚼器官の適 応能力を超えた状態で病的変化や機能障害が認められる 咬合である. 病的咬合の場合, 咬合再構成が必要とされ る場合が多い2).

本症例は $76 \mid 67$ の近心傾斜によりスピーカーブは強
く, その結果 $7 \mid$ に早期接触が生じ, 下顎位が前方に変位 し, この状態で咬合が確立 $(\mathrm{CR} \neq \mathrm{ICP})$ し，二態咬合 となったと考える。この咬合状態で不適切な治療を繰り 返した結果，残存歯に外傷性咬合が加わり，垂直性の骨 吸収を伴う中等度歯周炎を発症した病的咬合であり，咬 合再構成が必要であると診断した。

Lee ${ }^{3)}$ による咬合再構成の治療指標を図 17 に示す. 


\section{Bio-esthetic and Function}

- Centric condylar position with disk in place

- Cuspid guidance

- Anterior guidance

- Centric stops for all centric cusp

- Class 1 buccal segment relationship

- Over Bite : $4 \mathrm{~mm}$

- Over Jet : 2 3mm

Robert L Lee

図17 全顎治療の指針としてLeeが示した基準3)

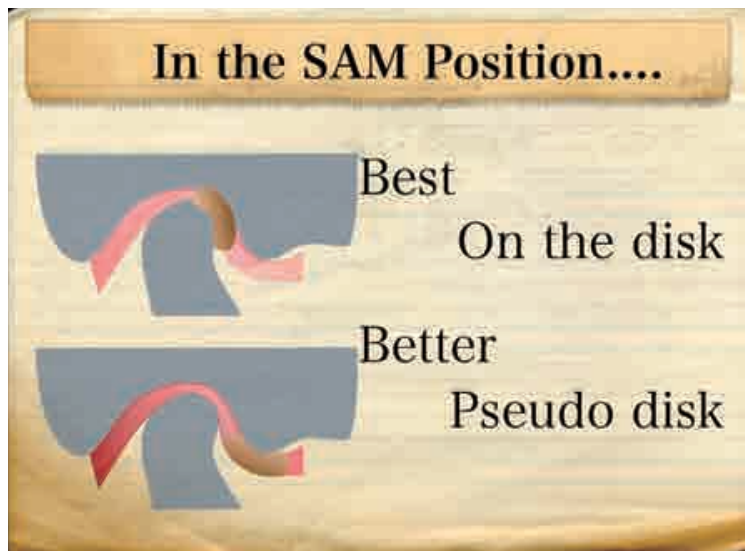

図19 下顎頭の位置は理想的には関節円板を介して下 顎頭の前上方部が関節円板の最も薄い無血管性部分を 介在して関節隆起と相対する上下顎の位置関係である が，そうならないケースもあり，そのような場合は顆 頭安定位で関節後部組織を肥厚させ (pseudo-discal tissue ），偽関節円板として機能させる

病的咬合を咬合再構成する場合の顎位のゴールは中心位 と考える．中心位の定義は図 18 に示すように GPT-8 4) では種々の見解が示されているが, 一般的には「下顎頭 の前上方部が関節円板の最も薄い無血管性部分を介在し て関節隆起と相対する上下顎の位置関係」とされること が多く, Leeもまた「Centric condylar position with disk in place」と述べており, 筆者も理想的な下顎位と考え ている.

しかし，咬合再構成治療を必要とする病的咬合の患者 の多くは, 関節内の関節円板の非復位性偏位や, 骨関節 炎あるいは骨関節症状が存在し, また下顎頭の形態的左 右差, あるいは下顎骨体の変形など, 様々な問題を抱え ており，定義通りの中心位を得ることは困難である.

Lee は「スプリントは筋の緊張を和らげ，顎関節を 安定させる働きがある」と述べている ${ }^{3)}$. また, 荒谷

\section{Centric Relation}

1. anterior - superior position, superiorly and anteriorly

2. most retruded physiolosic relation

3. most retruded relation, most posterior unstrained position

4. most posterior position

5. midmost, uppermost position, most superior position

6. uppermost and rearmost position

7. anterior uppermost position

GPT-8

図18 アメリカ歯科補緅用語集 (Grossary of Prosthodontic. Terms-8) 4)

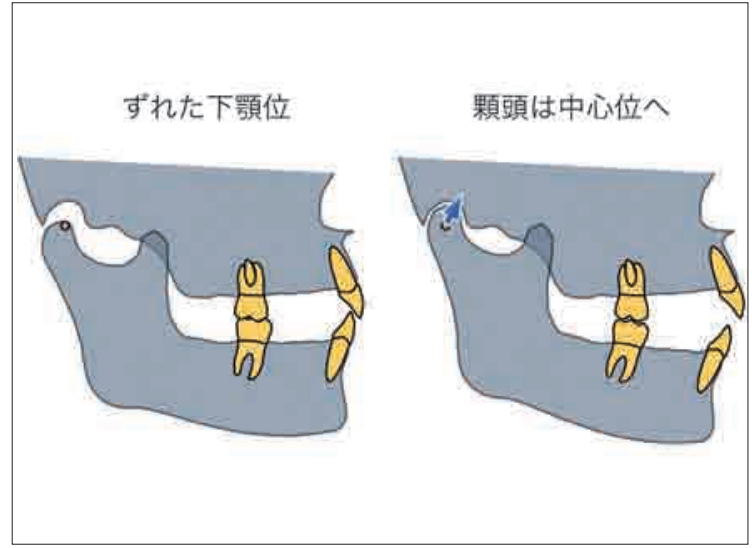

図20中心位に下顎頭が位置すると下顎骨は反時計回 りに回転（クロックワイズローテーション）し，早期 接触により咬合高径は高くなる.

は「安定した顆頭位獲得のためにスプリント療法は不可 欠であり，スプリントの長期使用によって顆頭安定位 (Stable Condylar Position：SCP) が得られる」と述べて いる5)。これらの理由によりスタビリゼーションスプ リントを用いて得られた顆頭安定位が臨床的に有効な方 法と考える。

荒谷はスプリントによる顆頭安定位での顎関節内の変 化について，「関節後部組織は生体における適応と修復 の機序により，緻密な線維性結合組織，いわば関節に変 わる耐圧組織として機能することが可能である」と述べ ている 5)。また, Dawson もスプリントを用いることで 偽円板形成を働きかけることを期待しながら，関節円板 後部組織における圧縮力を減少させることができると述 べている 6).

臨床的には長期的なスタビリゼーションスプリントを 
装着, 調整を繰り返すことにより, 安定した下顎位に おいて関節後部組織を肥厚させ（pseudo-discal tissue）, 偽関節円板として機能させることである（図 19）.

本ケースにおいて長期スプリント装着により安定した 顆頭安定位を元に咬合器上で咬合調整をシュミレーショ ンし，診断用ワックスアップを行い，プロビジョナルレ ストレーションに反映させた.

顆頭安定位に下顎位が収束すると一般的に下顎はク ロックワイズローテーションを生じ, 早期接触によって 咬合高径は高くなる. Dawson ${ }^{7)}$ は安易に咬合高径を挙 上することの危険性を述べており, 高くなった咬合高径 を患者固有の咬合高径に戻すために咬合調整や補緅処置, あるいは矯正的な歯の移動により，下顎をカウンターク ロックワイズローテーションさせ咬合高径をコントロー ルする必要がある（図 20）。

本ケースでは切歯指導ピンを指標として行った咬合器 上で咬合調整をシュミレーションし，この調整を口腔内 で再現し，数日間その高径が患者に適応できるか（違和 感がないか，不快症状がないかなど）を確認した，その 後プロビジョナルレストレーションの作製を行っている. 治療期間中, $\overline{7 \mid 7}$ のプロビジョナルレストレーション の破損が認められた。これは長期の使用によるプロビ ジョナルレストレーション咬合面のすり減りと, 顆頭安 定位からわずかにずれていたので, 早期接触の回避に よって起きた現象, いわゆる avoidance pattern ${ }^{8)}$ が原 因と考えられる。 また，材質の劣化や偏心位での干涉も 考えられ，プロビジョナルレストレーションの再製作を

参考文献

1) MacNeil C : Sience and practice of occlusion : 306-313, Quintessence Pub (Chicago), 1997.

2）加來慶久：治療計画で考えるべきは何か?——患者個々 の病的変化, 時間軸を加味した治療概念の提案. ザ・クイン テッセンス, 30 (12) : 47 - 66, 2011.

3) Lee RL : Anterior guidance. In : Lundeen and Gibbs (eds.). Advances in occlusion. : John Wright Pub (Boston), 1982.

4) The Glossary of prosthodontics terms : J Prosthet Dent, 94(1) : 10-92, 2005.
行った. プロビジョナルレストレーションの再製作に先 立ち, 再度スタビリゼーションタイプスプリントを装着 し, 下顎位を顆頭安定位に収束させることで, より安定 した下顎位を得ることができたと思われる。

本ケースでは下顎位の安定の確認はスプリント上の咬 合接触の変化やセメントのウォッシュアウトの有無, 患 者の感覚などに依存した. より客観的に顎位の安定を確 認するためには CPI システムなどの下顎位を計測する システムを用いるべきであると考える.

\section{結論}

病的咬合における咬合再構成において，顎位の決定は 困難である。

スタビリゼーションスプリントによる顎位の決定は, 口腔内に不可逆的な変化を与える前に正確な診断が行え るほか, 患者固有の安定した顆頭位を具現化できる利点 があり, その後の補綴操作が容易に行え, 術後の顎位の 安定も得やすいものと考える.

本症例は術後まだ日が浅いため, 中長期的な予後観察 は必須と考えている.

\section{謝辞}

稿を終えるにあたり, 木原敏裕先生, 酒井昭行先生, 加來慶久 先生はじめ Facial Occlusion Study Club の諸先生方, 大分歯水会, $\mathrm{ADSCO}$ の諸先生方, Y's セラミックスの山下和正様, 当医院のス タッフと家族に心から梁く感謝申し上げます。

5）荒谷昌利：顎口腔システムから「咬合」を理解する 第三 回 Bioesthetic Dentistry の第一原則 Stable Condyle Position. ザ•クインテッセンス, 29 (3) : 114-124, 2010.

6） Dawson P E : ファンクショナル・オクルージョン. : 34-44, 医 歯薬出版(東京), 2010.

7） Dawson P E : ファンクショナル・オクルージョン. : 98-116, 医 歯薬出版 (東京), 2010.

8）荒谷昌利：顎口腔システムから「咬合」を理解する 第四 回 下顎の回避パターンとコンタクトガイダンス. ザ・クイン テッセンス, 29 (4) : 108-118, 2010. 